\title{
VIRGIN COCONUT OIL (VCO) MENUJU PRODUK UNGGULAN KABUPATEN LANGKAT
}

\author{
Joko Suharianto ${ }^{1}$, Adek Cerah Kurnia Azis' ${ }^{2}$, \\ Putri Sari Margaret Julianty Silaban ${ }^{3)}$ \\ Universitas Negeri Medan \\ djoko@unimed.ac.id
}

\begin{abstract}
ABSTRAK
Tujuan utama dari Kegiatan Pengabdian Kepada Masyarakat ini, menyelesaikan permasalahan mitra, yaitu dalam pembukuan keuangan usaha dan permasalahan dalam pengemasan produk Virgin Coconut Oil (VCO), dimana kedua item ini yang menjadi prioritas permasalahan utama yang sedang dihadapi mitra saat ini. Berdasarkan permasalahan yang ada tersebut, maka tim pengabdi memberikan solusi dari kedua permasalahan tersebut di atas, dengan melakukan pelatihan, pendidikan, pendampingan, sosialisasi, dan penyerahan inovasi model pengemasan. Kegiatan ini dilakukan dalam hal perbaikan pembukuan keuangan dan perbaikan dalam pengemasan produk $V C O$. Metode yang dilakukan dalam kegiatan ini yaitu dengan melakukan pendekatan dengan mitra. Adapun yang menjadi output pada kegiatan ini yaitunya: a). Adanya pembukuan keuangan usaha mitra yang sudah baik dan benar dan b). Model pengemasan baru yang terdiri dari: logo produk, brand, gambar ilustrasi, slogan, komposisi, alamat dan nomor handphone yang bisa dikunjungi dan dihubungi, serta hal-hal lain yang berhubungan dengan desain kemasan. Sedangkan untuk luaran dari Pengabdian Kepada Masyarakat ini akan menghasilkan a). Buku panduan dan buku besar pembukuan keuangan; b). Inovasi kemasan produk $V C O$; c) Alat-alat yang digunakan untuk proses pengolahan $V C O$; d). Publikasi media massa cetak/online; d). Video kegiatan diupload di youtube; e). Prosiding seminar Nasional yang ber-ISBN online dan cetak, dan f). Artikel dalam jurnal Nasional ber-ISSN online dan cetak.
\end{abstract}

Kata kunci: $V C O$, Produk, Unggulan, Kabupaten, Langkat.

\begin{abstract}
The main objective of the Community Service Activities is to solve partner problems, namely in accounting of business finances and problems in packaging Virgin Coconut Oil (VCO) products, where these two items are the main priority problems currently faced by partners. Based on the existing problems, the service team provided a solution to the two problems above, by conducting training, education, mentoring, socialization, and the delivery of innovative packaging models. This activity is carried out in terms of financial bookkeeping improvements and improvements in VCO product packaging. The method used in this activity is to approach partners. The outputs of this activity are: a). The financial books of business partners that are already good and right and b). The new packaging model consists of: product logo, brand, illustration images, slogan, composition, address and mobile number that can be visited and contacted, as well as other matters related to packaging design. As for the outputs from Community Service, this will result in a). Guidebooks and financial bookkeeping ledgers; b). VCO product packaging innovation; c) Tools used for the processing of VCO; d). Print / online mass media publications; d). Activity videos uploaded on YouTube; e). Proceedings of the National Seminar with online and printed ISBNs, and $\mathrm{f}$ ). Articles in the national journal ISSN online and in print.
\end{abstract}

Kata kunci: VCO, product, superior, district, Langkat.

\section{PENDAHULUAN}

Kabupaten Langkat adalah sebuah Kabupaten yang terletak di Provinsi Sumatera Utara, Indonesia. Ibu kota dari Kabupaten ini berada di Stabat. Kabupaten Langkat terdiri dari 23 Kecamatan, yakninya: Babalan,
Bahorok, Batang Serangan, Brandan Barat, Besitang, Binjai, Gebang, Hinai, Kuala, Kutambaru, Padang Tualang, Pangkalan Susu, Pematang Jaya, Salapian, Sawit Seberang, Secanggang, Sei. Bingei, Sei. Lepan, Selesai, Sirapit, Stabat, Tanjung Pura, 
dan Wampu, dengan luas wilayah 6.272 kilo meter persegi dan dengan jumlah penduduk 902.986 jiwa (Profil Kabupaten Langkat, 2017).

Salah satu Kecamatan yang cukup potensial di Kabupaten Langkat ini yaitu Kecamatan Hinai, Kecamatan yang memiliki 13 Desa ini mempunyai potensi alam dan Sumber Daya Manusia (SDM) yang cukup diperhitungkan di Kabupaten Langkat. Pemerintah Kecamatan yang bertekat untuk menjadikan masyarakatnya yang makmur ini, memiliki potensi yang beragam pada masing-masing Desanya, dari 13 Desa yang ada tersebut, ada satu Desa yang cukup dominan potensial dari segi Sumber Daya Alam (SDA) dan Sumber Daya Manusia (SDM) kreatifnya, di Desa ini ada sebuah Usaha Kecil Menengah (UKM) yang mampu mengolah hasil pertanian penduduk berupa buah kelapa diolah menjadi sebuah minyak yang memiliki beraneka ragam manfaat, diantara manfaatnya yaitu untuk kesehatan dan menjaga atau memulihkan stamina tubuh baik itu dengan cara diminum maupun dioles.

Desa yang berada paling Utara di Kecamatan Langkat ini adalah Desa Cempa, di Desa ini ada sebuah UKM yang diberi nama "Barokah", UKM yang dikelolah oleh Bapak Suratman ini mampu memproduksi minyak kelapa murni yang disebut dengan Virgin Coconut Oil (VCO) sebanyak 200 mililiter perharinya, dimana jika ditotalka selama satu bulan mampu memproduksi $V C O$ kurang lebih 6 sampai dengan 6.5 liter. Usaha yang sudah berdiri selama 10 tahun belakangan ini, mengemas produk minyak kelapa murni atau VCOnya menggunakan botol bekas, sisa dari minuman mineral atau minuman penyehat yang sudah dibuang, botol tersebut dibiarkan polos begitu saja tanpa ada merek dagang dan hal-hal lainnya yang berhubungan dengan brand produk sebuah usaha.

$V C O$ yang sudah dikemas dibandrol dengan haraga Rp.50.000,perbotolnya, dengan berat bersih 200 mililiter. Dalam 1 minggu Bapak Suratman mampu menjual 1.200 mililiter $V O C$, dengan penghasilan kurang lebih Rp.300.000,- dalam seminggunya. Penghasilan perminggu ini dapat ditotalkan dalam satu bulan berkisaran Rp.1.200.000,-. Hasil dari penjualan ini sering kali tidak dikelolah dengan baik, dimana tidak adanya pembukuan keuangan atau catatan sederhana tentang pembukuan keuangan, modal sering digunakan untuk keperluan lain dan labapun jarang juga diputar untuk peningkatan modal usaha berikutnya. Hal ini merupakan salah satu penyebab UKM VCO Barokah tidak dapat berkembang dengan baik. Reality yang ada di atas tentang pembukuan keuangan yang masih kurang baik dan tampilan pengemasan yang bisa dikatakan belum serius, merupakan sebuah masalah yang sedang dihadapi oleh UKM VCO Barokah, namun problem yang ada tersebut di atas tentunya dapat diatasi untuk mendapatkan solusi yang terbaik, sehingga UKM CVO Barokah yang dikelolah oleh Bapak Suratman menjadi maju dari segi ekonomi usaha dan tampilan pengemasan produk, yaitu dengan cara mendatangkan ahli atau pakar yang bisa memberikan solusi dan menyelesaikan permasalahan yang dihadapi oleh usaha ini tentunya.

\section{METODE PELAKSANAAN}

Pelaksanaan kegiatan yang dilakukan dalam Pengabdian Kepada Masyarakat ini, yakni sebagai berikut: a). Melakukan Focus Group 
Discussion ( $F G D)$ dengan mitra; b). Melakukan kegiatan pelatihan, pendampingan, pendidikan, dan sosialisasi tentang pembukuan keuangan, pengemasan, dan merek dagang; dan c). Serah terima buku panduan pembukuan keuangan, buku besar pembukuan keuangan serta serah terima kemasan botol VCO baru, hard copy dan soft copy merek dagang produk $V C O$.

Metode pendekatan yang dilakukan guna menyelesaikan persoalan mitra, sebagai berikut: observasi lapangan ke lokasi mitra, berkomunikasi dengan mitra, mengelompokan masalahan mitra, mencari problem solving, penentuan lokasi kegiatan (dalam hal ini mitra berperan untuk memfasilitasi tempat kegiatan), $F G D, \quad$ pelatihan, pendampingan, pendidikan, sosialisai, serah terima model kemasan baru, serah terima hard copy dan soft copy model merek dagang baru, pendampingan akhir, dan evaluasi kegiatan.

\section{HASIL DAN PEMBAHASAN}

Kegiatan Pengabdian Kepada Masyarakat ini menghasilkan luaran sebagai berikut: 1). Buku panduan pembukuan keuangan, 2). Inovasi kemasan dan merek dagang, 3). Mesin pemeras santan, dan 4). Alat dan bahan pendukung produktivitas $V C O$.

Berikut produk yang dihasilkan selama kegiatan pengabdian kepada masyarakat dilakukan:

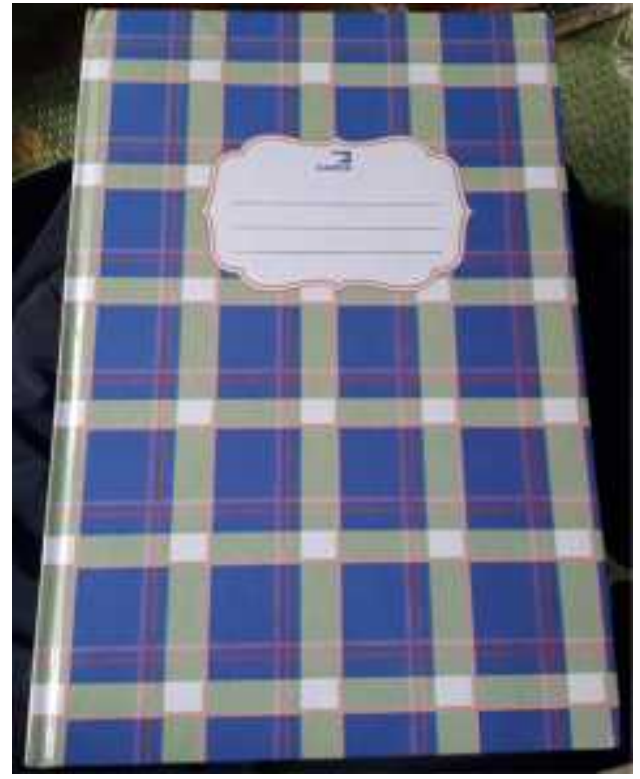

Gambar 1. Buku Panduan Laporan Keuangan yang Sudah Tersusun Rapi.

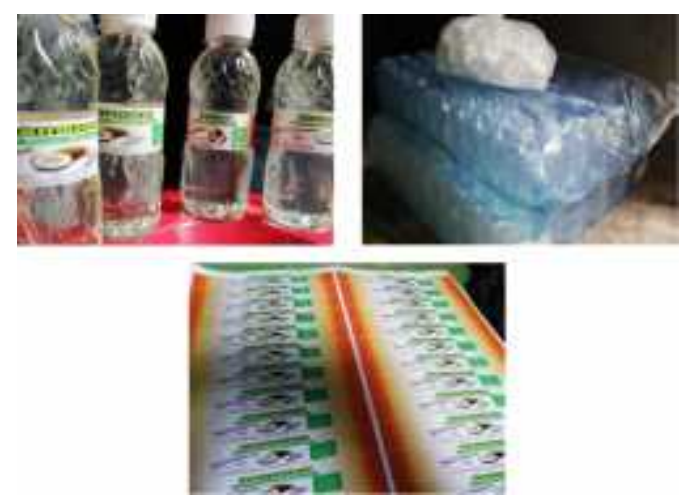

Gambar 2. Inovasi Kemasan dan Merek Dagang. 


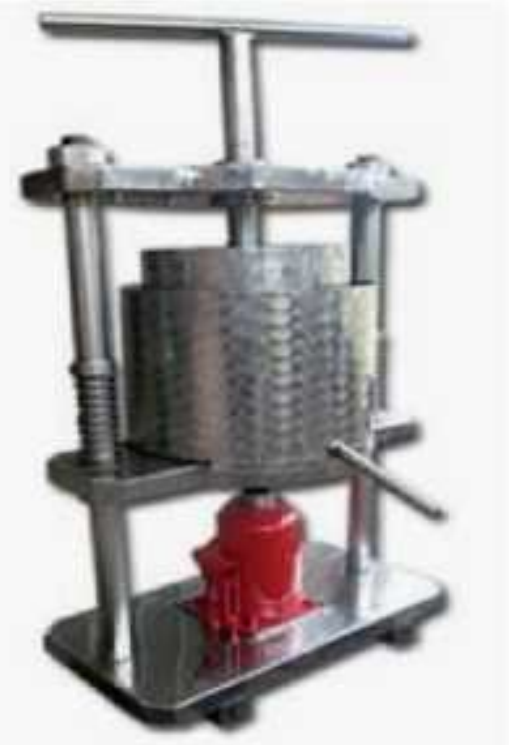

Gambar 3. Mesin Pemeras Santan.
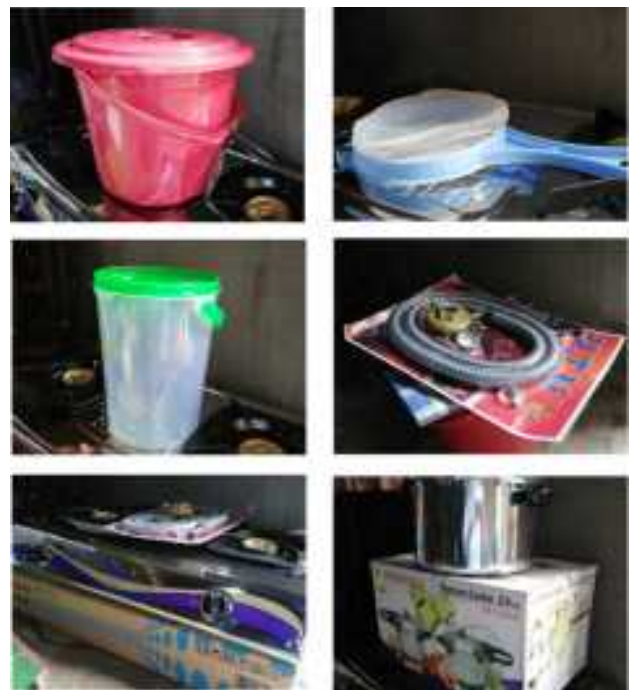

Gambar 4. Alat dan bahan pendukung produktivitas $V C O$.

Beberapa kepakaran yang dibutuhkan dalam pencapaian hasil kegiatan yang maksimal sebagai berikut: 1) Ahli Pembukuan

Keuangan Rasional: dalam kegiatan pelatihan, pendidikan, dan pendampingan yang dilakukan pada Usaha $V C O$ tentang penyusunan laporan keuangan, maka dengan itu perlu didatangkan pakar dalam bidang ekonomi, terkhusus perekonomian usaha kecil menengah dan 2) Ahli Desain Kemasan dan Pengemasan dengan rasional: dalam upaya mendesain merek dagang dan inovasi pengemasan produk menjadi lebih menarik lagi, yaitu dengan adanya pelatihan, pendidikan, pendampingan, dan sosialisasi yang langsung mendatangkan pakar dari Seni Rupa.

\section{KESIMPULAN}

Kegiatan Pengabdian kepada Masyarakat ini bertujuan untuk meningkatkan kualitas pembukuan keuangan, desain kemasan dan pengemasan, dan kualitas produktivitas usaha mitra yaitunya usaha vigin coconut oil (VCO) "Barokah" di Desa Cempa, Kecamatan Hinai, Kabupaten Langkat. Permasalahan yang dihadapi oleh Mitra di sini yaitu; (1) pengelolaan keuangan bisa dikatakan belum maksimal dimana hanya menggunakan kertas bekas, penghitungannyapun hanya bersifat gali lobang tutup lobang (tidak ada perhitungan modal dan laba, tidak jarang modal dan laba digunakan untuk keperluan lain) dan (2) pengemasan produk $V C O$ menggunakan botol bekas air miniral atau minuman penyegar, itupun belum adanya merek dagang.

Solusi yang ditawarkan di sini, Mitra diberikan pelatihan, pendidikan, pendampingan, sosialisai, dan penyerahan Teknologi Tepat Guna (TTG) mengenai permasalahan yang dihadapi oleh Mitra. Target khusus yang telah dicapai dalam pengabdian ini yaitu: (1) panduan pembukuan keuangan dan pembukuan keuangan menggunakan buku besar yang dirancang untuk menghitung keuangan usaha sudah baik dan benar dan (2) serah terima inovasi kemasan dan merek dagang, mesin pemeras santan, serta serah terima alat dan bahan pendukung untuk peningkatan kualitas proses produksi produk $V C O$. Metode pelaksanaan program pengabdian 
dilakukan secara berjenjang, berkesinambungan, dan komprehensif yang dilaksanakan melalui metode pendekatan. Pendekatan di sini dimaksudkan adalah perolehan informasi awal hingga proses kegiatan dilakukan dengan komunikasi secara langsung atau lewat alat komunikasi secara intensif dengan Mitra, sehingga pelaksanaan kegiatan dapat dilakukan secara terbimbing, dengan tujuan utama untuk meningkatkan kesejahteraan Mitra dalam mengelolah Usaha Kecil Menengah (UKM)nya, yaitu Virgin Coconut Oil (VCO) "Barokah" di Desa Cempa, Kecamatan Hinai, Kabupaten Langkat.

\section{REFERENSI}

Pemerintah Kabupaten Langkat. (2017). Profil Kabupaten Langkat. Langkat: LPM Unimed. 